\title{
THE BOARD OF SUPERVISION AND THE SCOTTISH PAROCHIAL MEDICAL SERVICE, 1845-95
}

\author{
by \\ STEPHANIE BLACKDEN*
}

\section{INTRODUCTION}

The parochial medical service as operated by the poor law authorities in both England and Scotland during the nineteenth and early twentieth centuries has sometimes been regarded as the forerunner of the modern British national health service. Indeed, Ruth Hodgkinson in her book The origins of the National Health Service ${ }^{1}$ deals with a formative period of the English poor law medical service, and says little or nothing about Scotland, where the overall supervision of poor law administration lay with the Board of Supervision in Edinburgh between 1845 and 1894, and thereafter with the Local Government Board for Scotland.

This study looks at the part played by the Board of Supervision in influencing the parochial medical service to the physically ill during this fifty-year period. The Board were very much concerned with medical aid to the sick poor and could justifiably claim to have had an effect on the development of the service. Obviously, any improvement that took place over these years was the product of a number of influences-social, economic, and politica-which had a bearing on the development of basic social services such as poor relief. On the medical side, advances in medical theory and practice, in public health provision, and in the organization of the medical profession, equally affected parochial medical aid. Nevertheless, in 1845, when the poor law came into effect, fewer than half the parishes provided medical relief to the paupers and centralized authority was conspicuous by its absence. By 1894 , in contrast, medical relief was established in virtually every parish. There was almost complete uniformity of practice in the

*Stephanie Blackden, PhD, The National Trust for Scotland, Kellie Castle, Pittenweem, Fife.

$\begin{array}{ll}\text { Abbreviations: } \\ \text { The Board } & \text { The Board of Supervision } \\ \text { PP } & \text { Parliamentary Papers } \\ \text { PB(M) } & \text { Parochial Board (Minutes) } \\ \text { PC(M) } & \text { Parish Council (Minutes) } \\ \text { RC } & \text { Royal Commission } \\ \text { q } & \text { Question } \\ \text { App } & \text { Appendix } \\ \text { LGB } & \text { The Local Government Board for Scotland }\end{array}$

${ }^{1}$ Ruth G. Hodgkinson, The origins of the National Health Service. The medical services of the New Poor Law, 1834-71, London, Wellcome Institute for the History of Medicine, 1967. 


\section{Stephanie Blackden}

administration of the poor law and its medical services, all parishes being subject to the same laws and methods of control and supervision by the central authority. In view of this, it is worth studying the centralized Board to see what influence it may have had in reshaping parochial medical care, from the low level at which it was available when the Board began work in 1845 to the service as it existed when the Board was replaced by the Local Government Board for Scotland in 1895. How many of the advances that took place were due to the Board's activities and how many to external factors is, of course, difficult to evaluate. However, it is the purpose of this study to examine the expansion of the Board's power in the years after 1845, and to trace its influence on the operation of the medical service at parochial and poorhouse level.

The article begins by looking briefly at the medical aid available to the sick poor before the Act of 1845; the medical clauses of the Act are then considered and the means for enforcement through a centralized Board of Supervision. The major part of the study looks at the methods used by the Board to expand its influence and at the application of the law under its direction in parishes throughout Scotland. A final section attempts an assessment of the Board's achievement. It has not been possible to include a discussion of the role of the Board in public health improvement, and of the Board of Lunacy in the care of the insane poor, although both Boards' responsibilities in these areas had an important effect on their relationships with the parishes and increased their opportunity for interfering in parochial administration very considerably.

At the outset, one important point needs to be made. The efficacy of parochial medical aid throughout the period is debatable. There were almost no effective drugs available. Few paupers received hospital treatment, and of those who did, only patients undergoing conventional surgery in the final decades of the nineteenth century had a reasonable hope of a cure by direct medical intervention, as opposed to mere relief of symptoms. ${ }^{2}$ A minority contemporary opinion believed that supplying the poor, or anyone else, with drugs and the attendance of a medical practitioner was a waste of money, because the sick would either recover through constitutional resilience or die in spite of the doctor's efforts. ${ }^{3}$ Many modern commentators on nineteenth-century medical treatment would concur in this judgement. Nonetheless, a majority of citizens, both rich and poor, in 1845 and after, held that medical men played an essential role in recovery from sickness or in preventing epidemic disease. The driving force behind the Board of Supervision's medical programme was fuelled by this belief, and for this reason the actual benefit or otherwise to the health of the sick poor of the parochial medical service is not under consideration here.

The reform of the Scottish poor law came more than a decade after that of England, through the Poor Law Amendment (Scotland) Act of 1845. Neither before nor after the 1845 reform was the Scottish poor law a carbon copy of that of

\footnotetext{
${ }^{2}$ Evidence of treatment and drugs prescribed can be found in the few surviving medical officers' Report Books, for example, the Report Book of the medical officer for South Ronaldshay, Orkney, c. 1900, 006/16/47 Orkney Islands Archives, Kirkwall.

${ }^{3}$ See Sir James Graham in Hansard, 12 June 1848, pp. 428-429; Aberdour Parochial Board Minutes, 13 May 1848; A. Harvey, Notes towards an outline of materia medica and therapeutic system and practice, Edinburgh, 1857, pp. 8-9.
} 


\section{The Board of Supervision and the Scottish Parochial Medical Service}

England. ${ }^{4}$ However, to make the Scottish system of poor relief understandable to those readers unfamiliar with its basic principles, a few of the more important differences between the Scottish and English systems are mentioned below and in the text, where appropriate.

In Scotland, both before and after 1845, each parish was responsible for the care of its own poor, and the reform measure brought no compulsory union of parishes as in England after 1834. In those smaller parishes which continued to raise funds by voluntary contributions, the kirk session and heritors remained in control of poor relief, although constituted for poor law purposes as a parochial board. There was no statutory obligation to raise poor funds by means of rates, provided sufficient funds could be raised voluntarily. As late as 1889 , fifty-three out of a total of 881 parishes still provided for poor relief through voluntary assessment. In 1845 , the number had been 650 . All parochial boards contained a proportion of non-elected members ex officio, and not until the Local Government (Scotland) Act of 1894 were all members of parish councils elected.

A fundamental difference between Scotland and England lay in the refusal to recognize unemployment as conferring entitlement to parochial relief in Scotland. Under the Scottish law, both before and after 1845, the able-bodied, unless disabled from work by other circumstances such as the care of young children, were not entitled to financial support from the parish. They could, however, be given relief at the discretion of the poor law authorities, for example during times of exceptional hardship. Even this latitude was removed following a court case in 1859, after which a claimant needed to be both destitute and disabled to qualify for parochial relief. Because of this deeply entrenched antipathy towards relieving the able-bodied, those who were accepted on to the poor roll were the deserving poor. Theoretically, the concept of "less eligibility" and the workhouse test were inapplicable to Scotland. Poorhouses were never workhouses, there was no statutory obligation to establish poorhouses, and the poor could not be compelled to enter those that were built, or to work in them. In practice, once the destitute had, in the words of the Board of Supervision, acquired "a more perfect knowledge of their rights" and were no longer content to accept poor relief as an act of charity, it was found necessary to introduce these English concepts into Scottish poor law administration as a means of distinguishing those genuinely needing help from those who should be discouraged. As the Board hastened to impress on the parishes, "a well regulated poorhouse is the best of all tests". ${ }^{5}$

The Board of Supervision was established by the statute as the central supervisory body. It contained nine members, six of whom sat on the Board by virtue of their office, and three of whom were government appointees. Of these latter, only one, the Chairman, was salaried, which limited the opportunities for political patronage. The legal profession was strongly represented by those members who held their appointments ex officio. Included among them were the Solicitor General for Scotland and three county sheriffs, as well as the Lord Provosts of Edinburgh and

\footnotetext{
4 Those wishing a more detailed explanation of the main differences between the Scottish and English poor laws should read Audrey Patterson's essay 'The poor law in nineteenth-century Scotland', in Derek Fraser (editor), The New Poor Law in the nineteenth century, London, Macmillan, 1976.

${ }^{5}$ Fifth annual report of the Board of Supervision, 1851, App A, p. 1.
} 


\section{Stephanie Blackden}

Glasgow. The Board had the unusual distinction of not being accountable to Parliament for its activities, although it was obliged to submit an annual report. ${ }^{6}$ It was never administratively as powerful as its English counterparts, but it achieved a small measure of financial independence, so far as the medical service was concerned, through control over the disbursement of the medical relief grant from 1849, and the lunacy grant from 1875. Meagre though these funds were, their distribution did give the Board a lever which it used very effectively to exercise some control over the parochial boards. In other respects, the Board had very limited control over the administration of the medical service, compared with the English poor law authoritics. Whereas in England and Ireland, poor law medical officers were appointed under the statutory rules of the central Department, the Board of Supervision in Scotland had no statutory duty to appoint medical officers and no powers of issuing Orders. Thus, it could not compel the parochial boards to appoint a medical officer, nor prescribe his qualifications. It could neither dismiss a medical officer nor prevent his dismissal by the parochial board employing him. Nor could the Board ensure he had a reasonable level of pay. Because of those differences, Scotland was never put on the same footing as England and Ireland with regard to the medical relief grant. The grant was fixed at $£ 10,000$ annually, instead of growing with expenditure as in England. This unequal treatment was a source of grievance to Scottish parochial authorities. Although the amount was eventually doubled to $£ 20,000$ in 1882 to keep pace with the increased expenditure since 1849 , the grant continued to be a fixed sum which, relative to Scotland's population when compared with England and Ireland, was half of what it would have been had Scotland been given the same proportion of medical relief as England.

Poorhouse hospitals developed later in Scotland than in England, and by 1909, only one parish, Glasgow City, had built an infirmary detached from the poorhouse site. The employment of pauper nurses was another aspect of the medical service where the Scottish system differed from that of England. Pauper nurses were employed in the smaller Scottish poorhouse sick wards until the First World War, and in 1909, twenty-six out of sixty-eight poorhouses had no trained nurses on the staff.

THE OLD SCOTS POOR LAW AND THE REFORM ACT OF 1845

The traditional Scottish method of poor relief, prior to the Poor Law Act, depended on self-help among the poor, backed up by church contributions and the occasional voluntary assessment among the heritors. This system could have worked from a medical standpoint if rural Scotland had consisted of small, agricultural lowland parishes with one or two landowners, a low level of unemployment, and a sufficiently small population for everyone to be under the benevolent supervision of the kirk session; or if urban Scotland had consisted of pleasant country towns with sufficient local industry to maintain full employment, a number of small proprietors able to contribute towards support of the,poor, and minimal public health problems.

\footnotetext{
${ }^{6}$ Lack of accountability was one of the arguments for replacing the Board of Supervision with a new body, the Local Government Board for Scotland. This was proposed in debate by Mr Crawford, the Member of Parliament for Lanark North East. Hansard, 22 May 1884, p. 1026.
} 


\section{The Board of Supervision and the Scottish Parochial Medical Service}

In either case, there would have to be a wealthy enough population to provide a comfortable living to the local doctor, which would then enable him to give some of his time free to the sick poor. Although parishes approximating to this ideal could be found, ${ }^{7}$ particularly in rural areas, the majority were quite different. Scotland contained, in the central belt and western highlands, arguably the worst urban and rural conditions to be found anywhere in Great Britain. These two areas constitute a large proportion of the country, and in the highlands and islands the poor law was a mockery which could have disappeared altogether without making much difference to the lives of the local people. In these areas, aliments could be as low as $2 s(10 \mathrm{p})$ a year, and were a token gesture acknowledging the individual's status as a pauper rather than a means of support. ${ }^{8}$ Without the generosity of relatives and neighbours, often almost as poor as the paupers, many of the destitute would have starved. This system of poor relief undoubtedly forced the poor to depend upon each other in times of hardship. The encouragement of "sturdy independence" in the Scottish peasantry was a source of pride in Scotland and of envy in England.

It was, however, in the cities rather than the countryside that relief became a controversial issue. Immigrants crowding into urban and industrial areas, with no relatives or friends to support them when they fell on hard times, put an unbearable strain on public and charitable agencies for relieving destitution. It did not go unremarked that rapid population growth went hand in hand with an alarming increase in infectious diseases such as typhus, relapsing fever, and cholera. W. P. Alison, the professor of medicine at Edinburgh and the most outspoken critic of the unreformed poor law, had developed powerful arguments linking destitution to such diseases. In his pamphlets and speeches, he publicized his view that it was the destitute condition of the unemployed poor that was responsible for epidemics. Any reform of the existing poor laws, he pointed out, which failed to provide for the sick and was confined to the aged and disabled as previously, would contribute to the continuance of these diseases. ${ }^{9}$ Alison and his supporters were largely responsible for ensuring that the Scottish poor laws would be investigated at parliamentary level. The Royal Commission on the Poor Laws in Scotland, which reported in 1844, showed that less than half the parishes provided medical relief in the form of dispensary or hospital treatment, or the attendance of a general practitioner. ${ }^{10}$ Those parishes that paid for some form of medical relief for their sick paupers were concentrated in the main cities and the east coast counties from Berwick to the Moray Firth. Elsewhere, the standard of medical relief was extremely low, and in huge stretches of the north it was entirely absent. In these areas, a visit to the doctor might involve a journey of thirty miles or more over rough countryside with possibly

\footnotetext{
${ }^{7}$ For example, Birnie parish, near Elgin, whose minister, George Gordon, was a well-known amateur naturalist.

${ }^{8}$ This was admitted to the Royal Commission. For example, the minister of Poolewe in his evidence (PPXX, pp. 732-733, 1844), told the Commission that the poor got a pittance occasionally from the heritors, and otherwise had to beg from door to door.

${ }^{9} \mathrm{~W}$. P. Alison, Further illustrations of the practical operation of the Scotch system of the management of the poor, London, 1841.

${ }^{10}$ Royal Commission on the Relief of the Poor in Scotland, PPXX-XXV, 1844. For a full discussion of medical relief to the sick poor prior to 1845 , see I.Levitt and T. C. Smout, The state of the Scottish working class in 1842, Edinburgh, Scottish Academic Press, 1979, ch. 9.
} 


\section{Stephanie Blackden}

a sea crossing to be faced. Often the minister, or some educated member of the community, kept a medicine chest or prescribed simples from a medical or pharmaceutical textbook. Less frequently, a paternalistic landowner or local industry paid for the services of a doctor. In both these instances, the parish authorities relied on the benevolence of others for the provision of a medical service of sorts to their sick paupers. ${ }^{11}$

Apart from the remote west coast and islands of Scotland, the problem was certainly not lack of doctors. Most communities from Wick in the north to Dumfries in the south had at least one general practitioner. These unfortunate gentlemen were not only expected to provide services to the sick poor without charge, they were expected to dip into their pockets to provide medicines and, more rarely, cordials, and only occasionally were they given a small sum towards the cost of drugs. ${ }^{12}$ The parishes which provided the most medical aid to the destitute were Edinburgh and Glasgow. In the latter, for example, the poor law authorities performed a wide range of tasks. They employed seventeen district medical officers to take charge of the outdoor sick poor on the roll. They managed the Town's Hospital for the aged and infirm poor. They provided medicines to both outdoor and indoor sick poor from the Town's Hospital's dispensary. They subscribed to a number of medical charities, including the Royal Infirmary, the Eye Infirmary and the Lying-in Hospital, in order to gain admission for their sick paupers. Finally, they employed a full-time inspector to investigate claims for poor relief, the forerunner of the inspector of the poor after reform. This impressive list of activities exceeded that of any other parish, but behind the charitable façade lay a far less generous reality. None of the parochial medical officers worked full-time. During the limited hours they gave to their parochial duties, they had to provide medical care for a population of about 150,000 , who were packed into some of the worst housing in Europe. Admission to the Royal Infirmary and any other charity hospital was not automatic. Any pauper falling sick, unless he was suffering from an infectious disease or an accident, had to drag himself around looking for an elder of the parish and his district parochial surgeon to get the necessary papers. Only then could he qualify for admission to hospital or receive attendance and drugs through the outdoor medical service. One witness to the Royal Commission testified that the voluntary hospitals frequently discharged pauper patients before they were fully recovered, dumping them back into the community unfit and destitute. ${ }^{13}$ In all probability, the medical service that a rural parish

\footnotetext{
${ }^{11}$ This is discussed in ibid. See also the returns to a questionnaire sent by the members of the Royal Commission to all ministers in Scotland in 1842, upon which their information is based.

${ }^{12}$ There is evidence of this from all over Scotland in the replies to question 54 of the questionnaire (see note 11). A typical reply is Airth parish in Perthshire, where the heritors refused to pay the doctor's account on the grounds that it was illegal, "and the poor surgeon was left to give medicines and attendance for nothing". One medical man in the parish of Penicuik paid 596 visits to the poor during the year and provided medicines without receiving a farthing in payment from the kirk session. The replies give evidence of medical aid dispensed by ministers and other non-qualified men. For example, the minister of Small Isles on Skye "to the best of his power supplies the people with medical aid at his own expense", and kept a stock of medicines for the purpose. Landowners also provided the services of a surgeon in some parishes. For example, at Kinlochbervie the "noble proprietor gives $£ 60$ a year with free house and grazing for two horses and a cow" to the surgeon who was bound to attend the poor gratis. PPXXIV, 1844, App. Part IV, Returns to q. 54.
} 


\section{The Board of Supervision and the Scottish Parochial Medical Service}

provided through a single local general practitioner or a dispensary gave better attention to the pauper community than the medical service of the city of Glasgow. ${ }^{14}$

The sensational revelations of inadequate relief and the neglect of sick and lunatic paupers contained in the Report of the Royal Commission convinced Parliament of the need to reform the Scottish poor law. The once-admired Scottish system of poor relief was described in debate in very unflattering terms. The member for Renfrewshire said of it that "nothing could be more disgraceful than the present state of the poor in Scotland. The poor law system of Scotland has been praised, but directly the light was let in upon it the sturdiest Scotchman felt ashamed of it". ${ }^{15}$ Ashamed or not, the opponents of reform were a powerful pressure group that could not be ignored. The resulting Act was a compromise between preserving the old law where possible and eliminating its worst abuses. On the one hand, machinery was set up to prevent parishes from refusing relief to those entitled to it, or from paying totally unrealistic sums as aliment. On the other hand, the parishes retained much of their independence of action, parochial boundaries were left intact, and the able-bodied were not given automatic right to relief.

It would be reasonable to suppose that stringent statutory provision for medical aid would have been included in the 1845 Act, as the extremely low level of medical relief had provided a major platform for reform. The member for St Andrews, Edward Ellice, attempted to introduce an amendment making the appointment of a medical officer in each parish compulsory. The proposal was rejected on the grounds that it would not be practical in large highland parishes with scattered populations. Underlying this point of view was the more decisive objection put forward by Sir Robert Peel, that it would be wrong to give the people of Scotland a positive assurance that the poor should at all times be supplied with medical relief, since this promise might not be kept. ${ }^{16}$ The medical clauses as finally passed into law laid down the following provisions. First, a parochial board with a poorhouse must provide medical aid to the sick and infirm inmates through the appointment of a properly qualified medical attendant, paid a reasonable salary. Second, all parishes were required to use their funds to provide the sick poor with medicines, medical attendance, a nutritious diet, and cordials. Third, parochial boards could subscribe from their funds to charitable medical institutions. These three clauses, together with regulations obliging parochial boards to take charge of pauper lunatics, formed the basis on which the parochial medical service was built. The extent of outdoor medical aid was left vague and liable to wide interpretation. It was to be given, to quote a later Report, "in such manner as might be found practicable and might be considered most expedient and equitable in the circumstances of each parish", ${ }^{17}$ which was an

\footnotetext{
${ }^{13}$ PPXX, 1844, q. 5681, p. 325. Statement of Captain Miller, police superintendent of Glasgow. See also q. 5924-5, pp. 338-340, evidence of Dr Fleming, Glasgow.

${ }^{14}$ An example would be the parish of Abercorn on the Hopetoun estate, West Lothian. Berwickshire in the borders was remarkable for enlightened parochial administration. All but one of the county's parishes imposed a compulsory assessment for poor relief by 1840 . Most subscribed to the Kelso or Jedburgh dispensaries, or paid a local medical practitioner to provide medical aid to the sick paupers. Report on the state of the poor in Berwickshire, Edinburgh, 1841.

${ }^{15}$ Hansard, 12 June, 1845, pp. 423-424.

${ }^{16}$ Ibid., pp. 176-177.
} 


\section{Stephanie Blackden}

invitation to some parochial boards to do little or nothing. There was no obligation to appoint a parochial medical officer for the outdoor poor. There was no provision for in-patient care, except in the few poorhouse sick wards. ${ }^{18}$ There were no guidelines as to what constituted a reasonable salary for the poorhouse medical officer, or acceptable qualifications for medical attendants. There was never any suggestion that the Board of Supervision should always include a medical member to sit among the distinguished lawyers and municipal dignitaries who dominated the Board. However, the first Chairman, Sir John McNeill, was a surgeon and diplomat, brother of Lord Colonsay, and later son-in-law of the Duke of Argyle and was thus connected to the inner circle of Scottish ruling families. His appointment had the effect of putting the greatest amount of power wielded by any member of the Board into the hands of a medical man, and his influence can be seen from the commencement of their operations. To some extent, Sir John's appointment offset the effect of the Board's policy towards the medical profession, which was against limiting itself to the advice of a single medical practitioner. The Board usually preferred, at least in theory, a more flexible approach and to choose expert opinion from the profession as a whole. ${ }^{19}$

THE BOARD OF SUPERVISION AND THE SHAPING OF THE PAROCHIAL MEDICAL SERVICE

The Board of Supervision was the great innovation of the Act. As its name suggests, it was designed to fulfil a supervisory and advisory role, leaving initiative and responsibility with the parochial boards. Possibly benefiting from the experience of the English poor law legislation and the unpopularity of the Poor Law Commissioners, the Board was given no obvious powers of compulsion. Its primary responsibility was considering complaints for inadequate relief, which, if judged to be justified, empowered it to grant paupers certificates to appeal to the High Court. Among the apparently meagre powers given to the Board by the statute was the right to issue rules and regulations for the guidance of parochial boards. If these were then signed by a secretary of state, they were enforceable in a court of law. This right proved one of the most understated but significant weapons available to the Board. Over the years they were to issue a number of regulations, extract Minutes, and circular letters covering every aspect of parochial administration from office procedure to poorhouse sick diets. Comparatively few of the documents that the Board sent out were signed by a secretary of state and thus enforceable at law. However, the parishes found it difficult to sort out which of the many communications they received had to be put into effect, and which they could safely ignore, and many tended to err on the safe side. ${ }^{20}$ There were five basic

\footnotetext{
${ }^{17}$ Poor Law Amendment (Scotland) Act, 8 \& 9 Victoria, c. 83, clauses 66-69. The Report quoted is the Report of the Departmental Committee appointed by the Local Government Board for Scotland to enquire into the system of Poor Law medical relief, PPXXXIII, 1904, p. 10.

${ }^{18}$ There were only twenty poorhouses in Scotland in 1845 , mainly in the cities.

${ }^{19}$ Report of the Select Committee appointed to Enquire into the Operation of the Poor Law in Scotland, PPXI, 1870, q. 5244, pp. 260-261. This point of view is here expressed by the Secretary to the Board, William Walker.

${ }^{20}$ The minister of Bourtie, an agricultural parish in Aberdeenshire, confessed in his evidence to the Select Committee that he frequently ignored Board of Supervision circulars. Even so, he felt obliged to
} 


\section{The Board of Supervision and the Scottish Parochial Medical Service}

communications from the Board affecting the medical services. The first, issued in 1845 , very soon after the Act became operative, put responsibility for emergency medical aid on the inspector in each parish. The second, issued in 1848 and reissued and updated from time to time, laid down rules for medical relief. Both were signed and were complied with to a greater or lesser extent. The Board drew up rules for poorhouse administration in 1850 , which included regulations on the management of sick wards. These rules were unsigned, and poorhouse management committees were able to amend them to suit local conditions to a limited extent. In 1879, the Board issued rules for trained sick nursing in poorhouses, which were linked to the medical relief grant and thus had financial incentives for poorhouse managements. The fifth communication, issued in 1849 and reissued in 1854, required parishes to provide a house or room for lodging the homeless sick; it was unsigned and thus more frequently evaded.21

Enforcement was to be a problem for members of the Board of Supervision throughout their period of office. They had the right under the statute to consider and inquire into the management of the local parochial boards, and to apply to the Court of Session by a summary process if a board were not doing its duty. When faced with such an eventuality, few parochial boards were prepared to face up to such a formidable array of legal strength as the Board possessed. Apart from this ultimate weapon, the Board had to rely to a great extent on the inspectors of the poor. Every parish was required to appoint these inspectors, who occupied a middle ground between the Board of Supervision and the parochial boards. They were appointed by the local boards and were responsible to them for the day-to-day administration of the parish, but they could only be censured, suspended, or dismissed by the Board of Supervision, which was a precaution against unfair dismissal. It was their job to receive all the central Board's communications, put them into effect, and provide the Board with information when required. The duties of the inspector were arduous, as he was the official whom applicants for relief first approached. He had to investigate their claims, take emergency measures in cases of sickness or accident, and deal with a multitude of other problems including pauper lunatics. Inspectors were supposed to visit all paupers on the roll on a regular basis, at least twice a year, and report on their condition to the boards. These procedures were simple enough in a small, compact parish such as Birnie, near Elgin. But they were almost impossible in a geographically vast parish such as Lismore and Appin, part of which was an island and another part a peninsula of the mainland, which could only be reached by a sea crossing or a long detour overland on unmade roads. ${ }^{22}$ If things went wrong,

provide casual sick accommodation as it was an issue on which the Board obviously felt strongly. Ibid., q. 1092, p. 62.

${ }^{21}$ First annual report of the Board of Supervision, App. B, No. 3 and No. 10, 1847; Third annual report, App. A, No. 12, 1849; Fifth annual report, App. A, 1851; Fortieth annual report, App. A, No. 6, 1885.

${ }^{22}$ Very large parishes employed an assistant inspector whenever funds permitted or under pressure from the Board. Lismore and Appin employed an assistant for the island of Lismore. When this official died in January 1862 , they attempted to economize by allowing the position to lapse, on the grounds that the inspector lived near the ferry to Lismore and could attend to his duties on the island relatively easily. The Board insisted that the position be restored. Appin and Lismore at one time made use of the services of a local tradesman, who supplied the paupers in a remote part of the mainland parish with fuel and food and reported on their circumstances to the inspector. (Appin and Lismore PBM, 12 January and 6 February 1862; letter from Hugh Cameron, coal merchant, Kingairloch, 24 January 1872). 


\section{Stephanie Blackden}

inspectors usually took the blame, and their liability for prosecution for neglect of duty was established as early as 1847 when the inspector of Falkirk was indicted for culpable homicide after the death of a man from insufficient relief. ${ }^{23}$ Even understandable errors of judgement could result in dismissal. For example, in the 1870 s, the inspector of Galashiels was dismissed by the Board of Supervision after an investigation into the death of an old man found lying seriously ill by the roadside. The evidence would suggest that the parochial medical officer's tardiness was equally, if not principally, at fault. ${ }^{24}$

Over the years, the Board developed an efficient central inspectorate to investigate complaints or requests for help. To make such investigations, from the beginning, they employed two general superintendents, whose reports often revealed that parochial administration was far from satisfactory. The poorhouses were barred to their inspection until 1856, when the Board was empowered to appoint a visiting inspector. Once the poorhouses were open to scrutiny, again the conditions were found to be inadequate. ${ }^{25}$ The central inspectorate was one of the most successful means of enforcing reform and uniform procedures that the Board possessed. The general superintendents travelled very extensively, examined the books of the parochial boards and sat in on their meetings. Their subsequent report to the central Board was then communicated to the parish, which was expected to implement the recommendations. If they ignored them, and many did, the Board might have to put on pressure if the matter was sufficiently important to warrant this. ${ }^{26}$ After 1867, the inspectorate added public health to its remit through the Public Health (Scotland) Act of that year, although none of the inspectors was medically qualified.

Parishes which prior to 1845 were niggardly in providing medical relief to the sick poor were hardly going to change their habits overnight. In fact, one can find evidence of cost-cutting in the medical service into the twentieth century. ${ }^{27}$ In the years immediately after 1845 , parochial boards took advantage of the over-production of doctors and competition for a practice to make doctors tender annually for the appointment of parochial surgeon. The Board reported that this process "degenerated into a yearly contest between rival practitioners in which the most respectable and worthy were unwilling to engage and professional skill or fitness for office was a secondary consideration." ${ }^{28}$ There was often undignified

${ }^{23}$ Second annual report, p. ii, 1847-48.

${ }^{24}$ Poor Law Magazine, 1889-90, 32: 402-424.

${ }^{25}$ This was particularly true of the large city poorhouses, such as the Town's Hospital, poorhouse for Glasgow City parish, and the West End poorhouse of St Cuthbert's parish, Edinburgh. The Town's Hospital in Glasgow was originally designed as a private lunatic asylum, and was not easily adapted for the large numbers of paupers it was expected to house. In the poorhouse of St Cuthbert's parish, sick and insane inmates were not kept separate from the indigent as they should have been, and the site was encroached upon by railway development.

${ }^{26}$ Wick PBM, 20 September 1858; Resolis PBM, 12 June 1860.

${ }^{27}$ An example was Stirling parochial board. In the $1880 \mathrm{~s}$, the parochial board had no offices of its own but rented a room in a building which also housed the Council Chamber and Burgh Court. The parochial surgeon had to share an office with the inspector of the poor. He examined his patients, including female paupers, in a corridor with only a screen to give them privacy. (Undated newspaper cuttings, October/November 1883, XA.2/1/83, Central Regional Archives, Stirling.)

${ }^{28}$ Seventh annual report, p. vii, 1852. See also Poor Law Magazine, 1868, 11: 92-93 for a description of open rivalry between doctors, each supported by a faction of local people, who paraded through the parish 


\section{The Board of Supervision and the Scottish Parochial Medical Service}

lobbying and undercutting on the part of the doctors, and the lowest tender was invariably accepted. In the majority of cases, this sum was inclusive of drugs, an arrangement which might be reasonable in a country area far from a chemist, but inevitably it raised the fear that this could lead to a situation where a doctor might cut down on medicines in order to increase the proportion of his salary available for medical attendance. Although the Board made efforts to encourage the separation of drugs from medical attendance, preferably through contracting with local druggists, some smaller parishes continued to pay an inclusive salary to the end of the period. ${ }^{29}$ Parishes not wishing to make a salaried appointment called in a doctor when necessary, with or without a retaining fee. The Aberdeenshire parish of Bourtie secured medical relief by paying the local doctor a retaining fee of one guinea and settling any account incurred for attendances and medicines. In 1869, medical relief in Bourtie amounted in total to $f 12 s$. $9 d$., which, deducting the guinea, meant the sum of $1 s$. $9 d$. (about $7 \mathrm{p}$ ) was spent in medical aid to ten aged and infirm paupers on the roll. ${ }^{30}$ Other parishes paid no retaining fee, and settled the bills presented by a local doctor once they were satisfied that the expense was justified. A year or more could go by with no payment at all under the heading of medical relief. ${ }^{31}$

Medical aid was one branch of parochial administration that over the first twenty years was hardly to rise in cost at all. The total sum expended in 1848 was $£ 30,339$ and twenty years later it was only $£ 2,000$ more, at $£ 32,858$. Thereafter it rose, but always trailed behind other areas of parochial expenditure. To put these modest sums into sharper focus, however, we need to look at the amount spent on medical relief in the first years after the passing of the Act. In the year to May 1846, a year which included a period prior to the Act, this was $£ 4,056$ for the whole of Scotland. In 1847 , it had risen to $£ 12,789$ a year; incidentally, when 120 parishes, with a combined population of 160,000 , provided no medical relief at all, in spite of the Act. By 1848 , it had more than doubled, to over $£ 30,000$. An increase of this magnitude in only two years calls for closer investigation of the causes for such uncharacteristic parochial generosity towards the sick poor. ${ }^{32}$

The first Board of Supervision to take up office had had to deal with nearly nine hundred parishes. All of these parishes were accustomed to autonomy in poor relief,

on the day of the election of a medical officer. Where tendering was resorted to, competition was fierce, and the range of prices offered reflected the determination or desperation of individual doctors. For example, at Kirriemuir in 1848 , tenders ranged from a low of $£ 16$ to a high of $£ 28$ for providing medicines and medical attendance to the whole parish. (Kirriemuir PBM, 7 February 1848.)

${ }^{29}$ Dunrossness PCM, 24 September 1908. The LGB had written, pointing out that it was objectionable to have the medical officer's salary include the cost of medicines, as this practice might tempt him to cut down the amount of medicines given.

${ }^{30}$ Select Committee, PPXI, 1870, q. 5204-5308, p. 265.

${ }^{31}$ Kirkton parochial board in Roxburghshire never appointed a medical officer, and there are no references to medical aid in the minutes between 1845 and 1860 , when a medical account for $£ 1.15$ was paid for medical relief. Kirkton, in 1885, had the second lowest rate of pauperism in Scotland and for several years had only one pauper on the roll, which in part explains the low level of medical aid. Kirkton parochial board was compelled to appoint a parochial vaccinator in 1863 , and to undertake certain public health duties from 1867. Most parishes which opted not to employ a regular medical officer referred paupers to a local general practitioner when necessary, and paid bills when presented to them. (Aberdour PBM, 8 August 1857.)

${ }^{32}$ Third annual report, 1849 , p. v. 


\section{Stephanie Blackden}

and many were suspicious that the creation of the Board was an underhand move to impose centralization on this branch of Scottish local government. The Board was empowered to intervene in a parish's affairs only in response to a direct application for assistance. It might have been left on the periphery of parochial administration, if the parochial boards themselves had not been unused to administration and uncertain of the legal implications of the new law. The parochial boards were also as deeply suspicious of each other as they were of the Board in Edinburgh, particularly over questions of settlement. ${ }^{33}$ The Board was thus drawn deeply into parochial affairs as the recipient of a constant stream of enquiries and complaints from parochial board members, their staff, ratepayers, paupers, and others, which in turn led them to draw up rules for the guidance of all parishes. They were careful to begin their work in an atmosphere of advice and conciliation rather than coercion, an approach to which they paid lip-service long after they had become authoritarian.

It was persuasion rather than compulsion that the Board chose as the most tactful way of implementing medical reforms. They combined two of their statutory powers, their right to issue rules and their control over the local inspectorate, to introduce medical regulations at a moment when the parishes were too disorganized to oppose them. Very early on, in October 1845 , when many parochial boards had still to be constituted, the Board issued rules, approved by the Secretary for State and thus obligatory, requiring inspectors to take the responsibility for obtaining immediate medical or surgical assistance in cases of sudden sickness or accident to paupers. These rules put the onus for emergency medical aid on the inspector, who was within the Board's control, rather than his board, which was not, although the latter had to approve the inspector's actions at the first meeting subsequently. The Board followed this up with a circular restating the medical clauses of the 1845 Act and the rules for inspectors, and requiring parochial boards to report the medical relief arrangements within their parishes, thus keeping the concept of medical relief to the forefront of parochial thinking. ${ }^{34}$

Over the next few years, many parochial boards, particularly outside the central belt and wealthier agricultural areas of the borders and north east, began to get into financial difficulties as decisions on matters of aliment or inadequate relief went against them and expenditure rose rapidly. At another particularly vulnerable moment in 1848, when cholera was imminent and many parts of the western highlands and islands were suffering the effects of the potato famine, the Board issued its legally enforceable regulations for medical relief. These regulations directed every parish to obtain the services of a qualified medical practitioner for the outdoor poor. Each parish was to supply the poor with medicines, medical and surgical appliances, sick-bed attendance, nutritious diet, and clothing when ill, an expenditure quite beyond the means of many parishes where sickness and pauperism

\footnotetext{
${ }^{33}$ The Board provided free arbitration and advice on questions of settlement until 1873, when this was withdrawn through increased pressure of work following the Public Health (Scotland) Act, 1867. Settlement disputes between parishes were acrimonious and frequently led to litigation. The Poor Law Magazine, published from 1858, contained accounts of disputes and subsequent judgments, as well as hypothetical cases, as an aid to inspectors and others faced with decisions on liability.

${ }^{34}$ First annual report, 1846 , p. xvi.
} 


\section{The Board of Supervision and the Scottish Parochial Medical Service}

were particularly prevalent. ${ }^{35}$ This was the stick, but it was followed by a carrot in the form of a $£ 10,000$ medical grant, a life-saving prospect to many harassed parochial boards, who were less concerned with their independence than with balancing their books.

The grant was to be divided up between the parishes according to a complicated system calculated on the total population of Scotland divided into $£ 10,000$, and effectively laid down the amount of money each parish was entitled to receive. ${ }^{36}$ However, it could only be claimed by those that had spent at least double their share. Those that qualified and chose to participate were paid a substantial proportion of their medical expenses, up to half in the early years, although as more parishes joined the scheme this proportion shrank correspondingly. There were strings attached in the form of additional rules giving the Board greater control over medical administration in participating parishes. Because of these rules, some turned down the grant. Among them was Glasgow City parish, which spent nearly $£ 12,000$ on medical relief every year, well above the $£ 500$ minimum necessary to receive the grant, but was unwilling to give up any independence of action. ${ }^{37}$ The grant also required a minimum level of expenditure which in some cases was higher than the parish was already spending even when the grant money was taken into account. Many smaller parishes were faced with a decision to refuse the grant or raise the money spent on medical aid to the required minimum. The parish of Aberdour on the Aberdeenshire coast, under its formidable minister George Gardiner, turned down the grant on the grounds "that if the object was to shorten the days and diminish the number of paupers no better plan could be devised than the appointment of a regularly paid medical staff with full power to deal out their destructive drugs ad libitum, thereby converting every pauper into a sickly patient". ${ }^{38}$ This outspoken comment won the parish immortality in the annals of the poor law, but it was an opinion shared by other communities and individuals, at the time if not later.

However, in the first year, 494 out of 881 parishes chose to collect their share of the grant. In doing so, they took a step away from financial and administrative independence. What is more, they could receive payment only if they could prove each expenditure by presenting a voucher, which meant stricter attention to detail and the Board's requirements than many were used to. The Board themselves admitted in their Third annual report of 1848 that their intentions in drawing up the Rules were "to make the arrangements for affording this description of relief more

\footnotetext{
${ }^{35}$ At the first meeting of Lismore and Appin parochial board on 16 September 1845 , the existing paupers on the roll were reported as getting an average aliment of $7 s .6 d$. per annum, a sum which was raised immediately to between $£ 1$ and $£ 3$. By 1847 , the parochial board was paying a total of $£ 9$ to one family on the roll, following a complaint of inadequate relief which was upheld by the Board of Supervision. Stornoway parochial board was forced to impose a legal assessment under the 1845 Act within a few months of taking up its responsibilities, as in February 1846 it had only $£ 34$ in funds, whereas it needed $£ 450$ to meet its commitments. (Lismore and Appin PBM, 3 August 1847; Stornoway PBM, 24 February 1846.)

${ }^{36}$ This is fully explained in the Report of a Departmental Committee appointed by the Local Government Board for Scotland to enquire into the system of Poor Law medical relief, PPXXXIII, 1904, pp. 6-8.

${ }^{37}$ Glasgow City PBM, 23 May 1848.

${ }^{38}$ Aberdour PBM, 13 May 1848 . This minute was quoted in the Third annual report in 1849 and again in the Poor Law Magazine, 1886, 29: 303.
} 


\section{Stephanie Blackden}

uniformly systematic and efficient than they have hitherto been". ${ }^{39}$ Participating parishes had to organize their medical relief on a sound basis. They had to engage the services of a qualified medical practitioner and to provide drugs, surgical appliances, nutritious diet, vaccination, and in-patient treatment when necessary. Whatever may have been the state of medical science in 1848 , as improvements in medical education and practice were introduced in the universities and teaching hospitals, these filtered down gradually through the medium of the general practitioners to raise the standard of medical aid to the sick poor. Speaking of the effect of the medical grant on the highlands and islands, J. P. Day has said "it is not too much to say that the entire population, paupers and non-paupers, of the highlands and islands owed their medical service to this grant", an opinion which is difficult to dispute..$^{40} \mathrm{It}$ gave the necessary financial incentive to poor and remote parishes to provide medical relief to their sick poor, and just enough money, backed up by private practice or work with local industries and with lighthouse and military authorities where available, to attract qualified doctors. After initial difficulties had been overcome and administering the Poor Law Act had become routine, the medical service was one of its most valued aspects. The popular image of the country doctor, as parochial surgeon and general practitioner over a wide area and much respected by his community, has some basis in fact. This is in contrast to the situation in much of England, where acceptance of a post under the poor law brought with it some loss of public respect and could be interpreted as a sign that the doctor had failed to establish himself successfully in private practice. In those parts of Scotland where there were few doctors, parish work was an integral part of the general practitioner's responsibilities to his community. In some areas, particularly the highlands and islands, appointment as parochial medical officer could mean the difference between making ends meet and financial disaster. For example, the parochial medical officer of Assynt in 1851 received $£ 25$ a year for this position, a further $£ 15$ as parochial medical officer of the adjacent parish of Edrachillis, but only $£ 20$ a year from private practice. The largest proportion of his income came from the Duke of Sutherland, who paid him $f 40$ to tend estate workers. As medical salaries rose towards the end of the nineteenth century even in these remote areas, communities went to great lengths to retain their doctors, providing them with housing and transport and guaranteeing them a more attractive salary through local medical associations or through generous subsidies from local landowners. ${ }^{41}$

The major epidemics of typhus and cholera between 1847 and 1853 gave a further opportunity for intervention to the Board of Supervision, backed up by more explicit powers of compulsion through the Cholera Acts. Even a highland parish unlikely to have a case of cholera nearer than fifty miles was required to make sure that medical

\footnotetext{
${ }^{39}$ Third annual report, 1849, p. v.

${ }^{40} \mathrm{~J}$. P. Day, Public administration in the highlands and islands of Scotland, London, 1918, p. 128.

${ }^{41}$ The Constitution and Rules of Shapansay Medical Association c. 1890, provide for medical attendance and midwifery care to members at reduced fees for a half-yearly payment of between $3 s$. $3 d$. (unmarried men) and 4s.6d. (households). D1/5/1, Orkney Islands Archives. See also the return of the medical practitioner of Assynt to a Committee of the Royal College of Physicians of Edinburgh investigating medical practice in the highlands and islands of Scotland, 1852, Royal College of Physicians of Edinburgh library.
} 


\section{The Board of Supervision and the Scottish Parochial Medical Service}

attendance could be provided, that a supply of medicines and disinfectants was on hand, and that insanitary areas were cleaned up. Where the prospect of cholera seemed remote, parochial boards ignored these instructions. However, even quite small parishes which happened to be on trade routes or near large towns, such as Stornoway on Lewis or Errol in the Carse of Gowrie near Dundee, felt sufficient fear of the disease to perform rudimentary cleansing procedures and keep stocks of medicines and disinfectants on hand. Stornoway's isolation was insufficient to protect it; as a port and major communications centre for the Western Isles it had cases of cholera in the harbour area in 1849 and $1853 .{ }^{42}$ Great cities were brought under the additional supervision of general superintendents from the General Board of Health in London in 1848 and 1853. In 1848, the two Glasgow parishes north of the Clyde were required to organize house-to-house visits by specially recruited visitors, usually medical students. They had to arrange for chemists to stay open day and night throughout the parishes; recruit twenty-three district medical superintendents with a small army of assistants; provide in-patient accommodation for victims and houses of refuge for contacts; and administer a total of twenty-six day dispensaries and thirteen night dispensaries, all under pressure from London. ${ }^{43}$ Not all urban parishes could be dragooned into this much expenditure and effort. Gorbals, a desperately poor parish on the south side of Glasgow, steadfastly refused in 1854 to expand its medical services to meet the cholera threat. Although the general superintendent from London, Dr Hector Gavin, appointed a medical superintendent for the parish and insisted on the appointment of medical assistants and on house-to-house visits, the parochial board refused to recognize his authority, dismissed the medical superintendent he had appointed, and ignored his instructions as to extra staff. At the end of the day when the treasurer presented his accounts, Gorbals' extra medical expenditure on cholera amounted to just over $£ 22 .{ }^{44}$ Facing an overtaxed Board of Supervision still probing the limits of their coercive powers, Gorbals in 1854 was able to maintain such an approach and escape the consequences. In later years, it was much more difficult, certainly for smaller parishes, to evade at least an investigation. One small parish which in 1866 chose to ignore all the cholera regulations sent to their inspector by the Board of Supervision was Methilhill in Fife. Unfortunately, the village became the focus of a very virulent epidemic, and the Board appointed Dr Henry Littlejohn to investigate the causes of the outbreak. His report was later included in the Annual report of the year, which was a further humiliation to the chastened parochial board. ${ }^{45}$ Such adverse publicity was obviously unwelcome in any community, and most of the heavily populated

\footnotetext{
${ }^{42}$ Errol PBM, 7 August 1848; 9 October 1849; 19 November 1853; 4 September 1854. Stornoway PBM, 11 January 1849-26 April 1849; 11 September 1853-8 May 1854. The Chairman of Errol parochial board, Lord Kinnaird, obtained advice direct from the General Board of Health's medical supervisor in Scotland, Dr Gavin, on measures to be taken during the 1853-4 epidemic. See also, E. A. Spriggs, 'Hector Gavin, MD, FRCSE (1815-55)- his life, his work for the Sanitary Movement, and his accidental death in the Crimea', Med. Hist., 1984, 28: 283-292.

${ }^{43}$ Sutherland, for the General Board of Health in London, reported on the measures taken in a lengthy Report. (PPXXI, 1850, App. A.) For an account of measures taken by the Glasgow parishes to combat cholera, see S. Blackden, 'The development of public health administration in Glasgow 1842-1872', unpublished Edinburgh University PhD thesis, 1976, ch. 16.

${ }^{44}$ Gorbals PBM, 16 February 1854; 15 May 1854.

${ }^{45}$ Twenty-second annual report, 1867-8, App. A, No. 10.
} 


\section{Stephanie Blackden}

parishes were more responsible, engaging extra medical and nursing staff during epidemics, and attempting to provide hospitals and dispensaries and to clean up the most insanitary districts. Admittedly, most of these activities were prompted by fear of the disease rather than of the Board of Supervision, and once the emergency was over such measures subsided or were abandoned altogether. Nevertheless, basic public health procedures had been introduced in many parishes where they had not existed before, and in some places something of them survived after the crisis had passed. ${ }^{46}$

A more detailed discussion of the role of epidemic disease control in increasing the Board of Supervision's involvement in parochial affairs belongs more properly to a consideration of their public health responsibilities. However, the points raised above illustrate how emergencies such as nationwide epidemics provided opportunities for an extension of power not otherwise available, particularly when used to compel enforcement of the parishes' statutory obligation to prevent and relieve epidemic disease. Other national emergencies also gave opportunities to the Board to become directly involved in parochial administration. The failure of the potato crop and widespread distress in the western highlands and islands in the late 1840 s and early '50s provided the Chairman, Sir John McNeill, with an opportunity for personal investigation. ${ }^{47}$ The generally low standard of parochial administration, together with the need to instruct inspectors and parochial boards in the operation of the Act, contributed to the appointment of a general superintendent who was to have special responsibilities in this part of Scotland. This provided the Board with an excellent opportunity to train local inspectors to perform their duties according to the Board's ideals. ${ }^{48}$

Infectious diseases were frequently found to be carried from one parish to another by tinkers, vagrants, and those travelling in search of work. To solve this problem, the Board from 1848 onwards tried to persuade every parish to provide accommodation for all the casual sick found in parochial bounds. Many boards complied, even if this meant renting a shack and installing basic furniture and an elderly pauper woman to look after any sick lodged in it. However, a number of other parishes took no notice of the Board's demands, evading them into the twentieth century. For example, as late as 1905, the parish council of Clyne in Sutherland repeatedly held over consideration of a casual sick-house to a later meeting "when more members should be present". ${ }^{49}$ In such a situation an inspector was in a difficult position, as a death

\footnotetext{
${ }^{48}$ Glasgow City and Barony parishes maintained special committees originally convened to deal with the emergency, which then became the nucleus for their Medical and Sanitary Committees. (Blackden, op. cit., note 43 above, pp. 204-205, 408.) Drainie parish, which included the fishing port of Lossiemouth, opened a cholera hospital in 1849. It was retained until 1898 at least, and during the intervening years served as a smallpox hospital, a casual sick house for infectious cases, a store for dead paupers' effects, and a scarlet fever hospital. (Drainie PBM, 28 November 1898.)

${ }^{47}$ Report by Sir John McNeill on the Western Highlands and Islands, PPXXVI, 1851.

${ }^{48}$ This process had begun before the McNeill Report, during a visitation of the "distressed districts" of the Western Highlands and Islands by two of the Board's officers, O. G. Campbell and W. A. Peterkin. Second annual report, 1847-8, App. B, No. 3.

${ }^{49}$ Clyne PBM, 24 March and 13 October 1903; 18 March 1913. At Callendar, the sick nurse employed at the casual sick house was described in 1878 as "old and frail and needs to be replaced". (Callendar PBM, 23 November 1878.) Errol parochial board voted to obtain a two-roomed house to be put in charge of a "respectable widow". (Errol PBM, 6 November 1854.)
} 


\section{The Board of Supervision and the Scottish Parochial Medical Service}

through lack of such accommodation could theoretically bring him prosecution for neglect of duty. Most inspectors covered themselves by bringing the matter up at intervals for consideration by their boards. In this way, they deflected responsibility on to their employers, so that when a death did occur the Board of Supervision cleared the inspector of blame while severely censuring his parochial board in the Annual report. ${ }^{50}$

\section{THE MEDICAL SERVICE IN OPERATION}

By the time the Board of Supervision gave way to the Local Government Board for Scotland in 1895 , something approximating recognized medical procedures existed in all but the remotest parishes. One or more medical officers were employed, qualified according to the Medical Registration Act of 1858, who were expected to examine applicants for relief either at their surgeries or at the inspector's office before admission to the roll. Once admitted and possessing a pauper's ticket, the sick pauper was entitled to a domiciliary medical service, which required the doctor to visit him in his home day or night, even when this meant travelling long distances. $\mathrm{Dr}$ Taylor, who was parochial surgeon in Fetlar and South Yell in Shetland for thirty years around the turn of the century, describes walking ten miles over moorland to reach a patient. As his responsibilities involved a sea crossing, he devised an ingenious system of lights and a telescope, operated by the minister's son on Fetlar, to warn him when his services were needed there.$^{51}$ The parochial surgeon had also to attend at his surgery for a stipulated time daily and often dispensed medicines as well. Should he be ill or absent, he had to provide a qualified locum. The majority of the sick poor throughout the period 1845 to 1895 were treated in their own homes. In a few cases, small surgical operations were performed within the pauper's house. ${ }^{52}$ The parish authorities provided sick-nursing or attendance, a nourishing diet, and blankets, even if the attendance amounted to no more than a twice-daily visit from a neighbour or paying a woman to do washing and cleaning. A "nourishing diet", usually beef or beef tea, was very frequently ordered by medical officers, and probably did more good than all the medicines that they prescribed. The doctors themselves appreciated the value to undernourished patients of decent food at parochial expense. On occasions, they defended their prerogative as medical men to order sick diet, even then the parochial boards, to whom it was a charge which they could not offset against the medical grant, raised questions about the bills. ${ }^{53}$

\footnotetext{
${ }^{50}$ Second annual report, 1848, p. ii. For examples of parochial boards who accepted responsibility for a failure to provide casual sick accommodation, see Callendar PBM, 25 March 1882; Kilbarchan PBM, 18 June 1864.

${ }^{51}$ H. P. Taylor, A Shetland parish doctor, Lerwick, T. \& J. Manson, 1948, pp. 50-51. Dr Edwards, the medical officer of Cromdale parish, Inverness-shire, informed his board that he frequently had to go out at night in winter for ten to fifteen miles along roads blocked by snow "for the most frivolous of cases". (Cromdale PBM, 19 March 1860.)

${ }_{52}^{52}$ St Cuthbert's PBM, 27 September and 1 October 1850. Clyne PBM, 30 April 1907; 17 March 1908. In the Clyne case, the parochial medical officer was asked to perform an operation for hernia at the patient's home. The medical officer sensibly agreed to operate only on the condition that another medical man should be present to administer chloroform, and if the patient accepted the risk of the operation, since the doctor had found the cottage to be "extremely dirty". The operation was eventually performed at the Northern Counties Infirmary, Inverness.
} 


\section{Stephanie Blackden}

Pauper patients often grumbled about how much walking the system required of them. First they had to go to the parochial offices to obtain the inspector's authorization, thence to the doctor's surgery, and perhaps then to the authorized druggist for medicines. From the surgeons' point of view the domiciliary medical service was also demanding. No parochial surgeon could be fastidious-one police surgeon referred to the "coarse, dirty, often stinking linen of the poor". ${ }^{54}$ They had to be available at all hours, and their duties included a time-consuming maternity service which many resented. ${ }^{55}$ After 1863 , they had vaccination duties to perform, and there might be pauper lunatics to visit and certify. Unlike English parochial medical officers, they were not paid separately for maternity cases and the supervision of lunatics, these duties being included in their salary, although they were paid separately for vaccinations. Only a shortage of jobs or a simultaneous private practice could induce most doctors to stay, yet surprisingly some remained in remote areas for years at a time.$^{56}$ These cases of heroic isolation were against the trend in the highland parishes towards the end of our period, when parochial boards began to find great difficulty in getting doctors to stay. Some young graduates were willing to take up a post for a year or so, using the service as a stepping-stone in their careers, but few with any ambition or talent were willing to give years of their professional lives to remote country practice. ${ }^{57}$ Serious financial problems also beset many parochial boards, who could not afford the increased salary necessary to induce doctors to settle. The days when the services of a medical man could be secured for $£ 5$ inclusive of medicines, the salary paid initially by some country parishes, had long since gone and sums of $£ 150$ or more had to be raised by parochial boards. This sum alone was insufficient. It needed to be supplemented by private practice, or by a direct subsidy by the local landowners, if the general practitioner were to be persuaded to remain in the community. Tourism came to the aid of more fortunate areas, but the remote, barren northlands were denied all but a small share of this bounty. ${ }^{58}$ Raising a

\footnotetext{
${ }^{53}$ Alva PBM, inspector's letter book, 28 February 1848; 9 August 1865. Wick PBM, 6 December 1865; Bonhill PBM, 5 February 1859.

${ }^{54} \mathrm{R}$. Buchanan and E. Hope, Husband's forensic medicine, toxicology and public health, Edinburgh, 1904 , p. 154.

${ }^{55}$ Ayr PBM, 22 October 1866.

${ }^{56}$ For example, Dr McRae resigned after serving as medical officer of Stornoway parish for fifty-seven years. By then, he was about eighty-four and quite deaf. (Stornoway PCM, 25 July 1906.) Dr Taylor, who practiced in Fetlar and North Yell, Shetland, was over thirty years in his practice. (See note 51 above.)

${ }^{57}$ Evidence of this point comes from a number of parishes studied, including Loch Carron in Ross-shire, Resolis on the Black Isle, Kilvichian and Kilfinnichan on Mull, and Glenmuick in Aberdeenshire. Two successive medical officers of the latter parish left to further their careers, one in the Indian medical service and the other in private practice in London. (Glenmuick PBM, 7 September 1880; 29 August 1882.)

${ }^{58}$ In order to fulfil the terms of the medical relief grant, which required participating parishes to employ a suitably qualified medical officer, some highland and island parishes looked far afield for a parish doctor. For example, the two adjoining parishes of Lochcarron and Applecross in Ross-shire engaged a $\mathrm{Dr}$ Cameron from Fort William some forty miles away over rough country. In 1859, two years after his appointment, the parochial board of Lochcarron described him as "remarkably attentive", which seems unlikely since he could rarely have made more than a routine visit. Island communities were the worst attended in regard to medical aid. Fair Isle, although part of Dunrossness parish in Shetland, was visited once or, at the most, twice a year. "When the tide race permitted", the medical officer of the Commissioners of Northern Lights, based on Orkney, came to perform vaccinations. (Lochcarron PBM, 3 February 1857; 7 February 1859. Dunrossness PBM, 12 December 1906.)
} 


\section{The Board of Supervision and the Scottish Parochial Medical Service}

doctor's salary did not automatically increase the proportion of medical relief grant to which a parish was entitled, although it was not illegal to make up the shortfall between the salary covered by the grant and the salary expected by the doctor from parochial funds. ${ }^{59} \mathrm{~A}$ small community such as Papa Westray in Orkney, with an absentee landlord, only around three hundred souls on the island, and a mere three paupers on the poor roll, was quite unable to justify a large increase in poor rates to supplement a doctor's salary, even with this concession. The parish council struggled for years to induce a doctor, usually a recent graduate and frequently a woman, to stay. They provided a boat, attempted to provide housing, and raised additional funds through a medical association. Finally, they found the task beyond their financial capacity. ${ }^{60}$ Similar communities had to await the arrival of the Highlands and Islands Medical Service after the First World War to get adequate medical care. ${ }^{61}$

The alternative to home care for the sick poor was in-patient treatment. Most cases requiring hospital treatment were the acutely ill and surgical cases, particularly where the prospect of a successful outcome seemed good. There was a strong resistance among the poor to hospitalization, which for many meant a journey far away from their friends and relatives. For example, the Edinburgh Royal Infirmary drew pauper patients from as far afield as Shetland. ${ }^{62}$ Apart from the Northern Counties Hospital at Inverness, there were no major charity hospitals in the north, and those established in towns outside the central industrial belt, such as the Dumfries Royal Infirmary and the Perth Royal Infirmary, had to provide a service for a large area. To overcome the resistance of the poor to in-patient care, the Board of Supervision adopted the line that it was the duty of all sick paupers to do their utmost to ensure their own return to health and independence. Some parishes, acting in the spirit of this policy, threatened to withhold relief if in-patient treatment was refused. ${ }^{63}$ Hospital treatment tended to be popular with parishes, because on discharge the patient could be struck off the poor roll as cured, and once this happened he was no longer eligible for relief. However, the cost of dispatching the sick to a distant infirmary could be very high. The spread of poorhouses after 1845

\footnotetext{
${ }^{59}$ This was the opinion of the LGB, conveyed to Papa Westray Parish Council. In this instance, the owner of the island used his authority to prevent the parish council from paying the doctor anything more than $£ 35$, on the grounds that the number of paupers, four with one dependent, did not warrant an increase. In a similar case involving Arrochar parish council, the LGB refused to sanction an increase, and put pressure on the parish council to lower the existing salary of the medical officer from $£ 80$ to $£ 20$, which they regarded as a more realistic sum. (Papa Westray PCM, 29 November 1902; Arrochar PCM, 10 December 1896.)

${ }^{60}$ During the period covered by the only Minute Book of Papa Westray parish council, October 1895 to June 1914, there were thirteen resident medical officers, mostly women. Few stayed longer than six months to one year, and periods between medical officers had to be covered by an interim medical officer living on the larger island of Westray.

${ }^{61}$ Highlands and Islands (Medical Services) Grant Act, 1913, 3 \& 4 George V, ch. 26. See also David Hamilton's article on this service in the Scottish Medical Journal, 24, 64.

${ }^{62}$ Surgical cases from Shetland went either to Aberdeen or Edinburgh Royal Infirmaries by steamers of the Orkney and Shetland Navigation Company, which took pauper patients and returned them to their home port free of charge. (Taylor, op. cit., note 51 above, p. 74.) Some 163 Shetlanders made the journey to Edinburgh between 1880 and 1885 , not all of them paupers, and stayed an average of forty days each. (Letter to Shetland Times, 27 June 1885.) The Glasgow and Greenock Royal Infirmaries served the same function for the Western Highlands and Islands.

${ }^{63}$ Resolis PBM, 23 April 1847; Dollar PBM, 7 December 1854 and 8 February 1855; Rhynie PBM, 16 January and 15 February 1854 .
} 


\section{Stephanie Blackden}

widened the options for in-patient treatment, as did the cottage hospitals towards the end of the century, although some expressly excluded paupers from admission. ${ }^{64}$

There were only twenty poorhouses in Scotland when the Act became operative, but by the end of the century this number had increased to sixty-six. Under Section 66 of the Poor Law Act, every poorhouse was required to appoint a medical officer at a reasonable salary. This official was obliged to provide regular attendance, and was liable to dismissal by the Board should he prove unfit, incompetent, or neglectful of his duties. Under Section 64 , any regulations drawn up by poorhouse committees for the management, discipline, and treatment of inmates, and for the dispensing and supply of medicines to the sick poor within institutions, had to be submitted to the Board for approval. These opportunities for intervention in poorhouse management became correspondingly more important as the number of poorhouses increased after 1860. More immediately, they provided an opportunity for the Board to frame model poorhouse rules in 1850 , which were subsequently adopted by poorhouse committees throughout Scotland. Although these rules were chiefly concerned with non-medical aspects of poorhouse management, they did contain detailed instructions relating to indoor medical relief. For years, these rules provided the framework for the administration of medical relief in poorhouse sick wards, but as they remained substantially the same until the end of the Board's existence, they inevitably became outdated and inadequate for conditions in the hospitals of major city poorhouses. Initially, poorhouse sick wards were of a very low standard and staffed by pauper nurses. ${ }^{65}$ Inmates requiring surgery or specialist treatment were still sent to one of the charity or specialist hospitals. ${ }^{66}$ However, the plans of any poorhouse built after 1845 had to be submitted to the Board of Supervision for approval, and once built the poorhouse had to receive its licence before paupers could be admitted. This regulation gave the Board some leverage in controlling construction and layout, and plans that failed to incorporate hospital accommodation in the complex were not usually approved. Among the first of the new generation of poorhouses was that of St Nicholas, Aberdeen. The construction of this major city poorhouse gave the Board an opportunity to publicize the plans and to issue recommended designs for the ideal town and country poorhouse in the Annual report for $1848 .{ }^{67}$ These included quite extensive hospital accommodation to the rear of the buildings. In the case of the rural institution, the recommended hospital complex was of a level of sophistication unlikely to find favour with parishes proposing to combine for the provision of a poorhouse. A scaled-down version of this ambitious blue-print became fairly general for country poorhouses. ${ }^{68}$ The plan

\footnotetext{
${ }^{84}$ See Gerard Cottage Hospital Minute Book, p. 293-294. The hospital, at Monifieth near Dundee only admitted paupers under exceptional circumstances. (Dundee University Archives MS 2/1/1.) Logierait parish got round the problem on one occasion by raising the aliment of a pauper woman to a sum sufficient to enable her to pay her own bill at the Aberfeldy Cottage Hospital. (Logierait PCM, 22 April 1907.)

${ }^{65}$ St Cuthbert's PBM, 4 January 1851 . A case had come under investigation of a baby who died of malnutrition when the nurse stole its food. See also City PBM, 19 May 1869.

${ }^{68}$ Parochial boards would subscribe to various medical institutions, such as the Royal Infirmaries, the Lock and Maternity Hospitals in Glasgow and Edinburgh and the Glasgow Eye Infirmary, to obtain privileges of admission for their paupers.

${ }^{67}$ Second annual report, 1848, App. B, No. 4.

${ }^{68}$ Surviving plans for the Black Isle Combination Poorhouse at Fortrose show this clearly. (Highland Regional Archives, Inverness.)
} 


\section{The Board of Supervision and the Scottish Parochial Medical Service}

provided for four sick wards, two for male and two for female patients, with possibly an examination room, separate bathing facilities, and apartments for one or more nurses.

The Act of 1845 required poorhouses to provide a medical officer, and smaller institutions fulfilled this responsibility by engaging the services of a local general practitioner who was supposed to visit daily.$^{69}$ Most of his work, from the surviving poorhouse medical report book examined, would be supervising the care of chronic sick and infirm paupers. ${ }^{70}$ In a number of villages it had been difficult to get attendants for fractious and incontinent old people. This problem had been an incentive for the spread of poorhouses, particularly in the north, where many such cases ended up in the sick wards. By the early twentieth century, country poorhouses such as the Orkney Combination Poorhouse at Kirkwall had virtually become homes for the elderly sick and infirm with no relatives to care for them. ${ }^{71}$ The Board maintained a tenuous supervision of poorhouse administration through a visiting inspector with responsibility in this area. However, as his duties covered the great city poorhouses as well as the rural ones throughout Scotland, his impact on individual institutions was slight. Nevertheless, there is evidence that a visitation and subsequent report led to the airing of unsatisfactory practices and their redress. ${ }^{72}$

The greatest challenge to the Board of Supervision's effort to improve in-patient care came from the great city parishes. Many of the city poorhouses, particularly those of the three Edinburgh parishes, Glasgow City parish and St Nicholas, Aberdeen, inherited antiquated buildings which were ill-designed for modernization in accordance with the thinking behind the 1845 reform. One of the earliest problems tackled by the Board was a scandal involving the Canongate poorhouse's treatment of an elderly sick inmate. ${ }^{73}$ Separate sick wards were rarely provided, and the general wards were overcrowded. Even where separate accommodation for sick and insane inmates existed, it was inadequately staffed and administered by parochial boards who believed that economy in the interests of the ratepayers was at least as important as treating the sick poor. ${ }^{74}$ Major poorhouse construction, such as Barony's Barnhill poorhouse, the new St Nicholas poorhouse in Aberdeen, and

\footnotetext{
${ }^{69}$ At Orkney Combination Poorhouse, Kirkwall, in the early twentieth century, the local general practitioners performed duties in rotation, each tour of duty lasting six months. (Orkney Poorhouse Minutes, 10 January 1902.)

${ }^{70}$ Logierait Union Poorhouse medical officer's report book, c. 1890. Tayside Regional Archives, Dundee, No. CP/LO/7/1. Patients were mainly the chronic sick and infirm. On admission, they were sometimes described as needing "to be well fed and cared for". Cases requiring more complicated medical treatment were sent to the Perth Royal Infirmary. Nevertheless, patients treated in the sick wards of this small poorhouse included sufferers from diabetes, cancer, heart conditions, and phthisis.

${ }^{71}$ Orkney Combination Poorhouse Minutes, 8 September 1911. Logierait Poorhouse Minutes, 23 January 1890. The poorhouse here was described as "very full of old, ricketty people all requiring attendance".

${ }^{72}$ Kincardineshire Combination Poorhouse Minutes, 19 May 1868. Logierait Poorhouse Minutes, 10 August 1870. This latter report was very unfavourable, particularly in its comments on the cleanliness of the institution.

${ }^{73}$ Second annual report, 1848-49, App. B, No. 1, Canongate Poorhouse inquiry.

${ }^{74}$ According to Dr Wright, the medical officer, the low level of heating in Barnhill Poorhouse during one particularly cold spell was responsible for a rise in the number of deaths in the sick wards. In some of the female wards, the temperature never rose above $48^{\circ} \mathrm{F}$ over a three-week period in December 1874 and January 1875. (Barony House Committee Minutes, 1 February 1875, pp. 470-474.)
} 


\section{Stephanie Blackden}

Craiglockhart poorhouse in Edinburgh, gave the Board an opportunity to improve indoor medical facilities. ${ }^{75}$ However, the Board proved to be powerless to force the Glasgow City parish to modernize or reconstruct their sick wards in the $1880 \mathrm{~s}$. This was so even though the conditions reported by the visiting inspector Malcolm McNeill in August 1880, and by Dr Henry Littlejohn, the Board's medical inspector, in December 1882, would normally have brought the ultimate sanction of withholding recognition of the poorhouse as adequate relief. ${ }^{76}$ To the City parochial board, wrestling with unparalleled problems of urban poverty and, as they claimed, unable to expand their poorhouse accommodation owing to a restricted site hemmed in by urban expansion, such a threat could safely be ignored. Had the Board sought legal means to close down the poorhouse, the consequence would have been the discharge of all inmates on to outdoor relief, an alternative even less acceptable to a Board actively encouraging indoor relief, particularly for "test cases". The way out of the dilemma eventually came for the City parish through a complete reorganization of the Glasgow parishes north of the Clyde, when Barony and City united to form the Glasgow Parish Council. This administrative reform, taking place in 1898, belongs to the period of parochial history following the formation of the Local Government Board for Scotland as successor to the Board of Supervision.

Through time, a combination of factors slowly forced a rise in the standard of poorhouse hospital care. Public opinion and medical advance were probably more important causes of this change than the efforts of the Board of Supervision. Gradually, the major advances in hospital treatment were adopted in the parochial infirmaries, and in the early twentieth century, by which time the Board of Supervision had ceased to be, a substantial hospital building programme was undertaken in the cities to separate the sick poor from the merely indigent. Some of Scotland's foremost medical institutions at present-Stobhill and the Southern General Hospitals in Glasgow, the Western General in Edinburgh, for example-started out as poor law hospitals. ${ }^{77}$

Nursing care was a problem, since good pauper nurses were difficult to recruit, outdoor relief being the usual method of relieving respectable women in Scotland. ${ }^{78}$ Those appointed often turned out to be unsuited to the work. Although a few paid nurses were employed and Barony parish engaged one or two trained nurses from the 1860 s, no Scottish parish had opted for the systematic employment of trained nurses

\footnotetext{
${ }^{75}$ Dundee year book, 1891, p. 114, describes the New Sick Hospital for Dundee's paupers. Govan parish poorhouse was opened in 1873, and had a training school for nurses by the end of the century. The Board of Supervision was not always successful. Aberdeen's poorhouse sick wards were chronically overcrowded. In spite of suggestions from visiting officer Malcolm McNeill that additional hospital accommodation should be added, it was not until 1907 that the Oldmill poorhouse hospital was opened with a training school for nurses. (Aberden PBM, 11 January 1887.)

${ }^{78}$ Glasgow City PBM, 5 April 1881; 16 December 1883. Report of Visiting Officer Malcolm McNeill and Dr Henry Littlejohn on hospital conditions at the Town's Hospital. Littlejohn's report is particularly depressing, recording chronic overcrowding, dark wards, and general lack of cleanliness and facilities for patients.

${ }^{77}$ Examples of this evolution are the Southern General Hospital which started out as Merryflats Poorhouse of Govan parish; and the Western General Hospital, Edinburgh, which today is a major teaching hospital and was built as the Craigleith Poorhouse of St Cuthbert's parochial board.

${ }^{78}$ Attempts to recruit nurses from the outdoor roll were sometimes made. See Canongate PBM, 6 April 1847; Glasgow City PBM, 19 May 1869.
} 


\section{The Board of Supervision and the Scottish Parochial Medical Service}

under the supervision of a lady superintendent on the lines developed in the voluntary hospitals and larger English workhouse hospitals by the 1880 s. The initial impetus came in 1879 from a Board of Supervision circular, and the following year, Barony parochial board engaged Miss Piggot of Guy's Hospital and a staff of trained nurses for their hospital wards. ${ }^{79}$ This initiative was not imitated by other poorhouses until the Board of Supervision introduced a nursing grant for each trained nurse engaged, participating poorhouse administrations having to employ nurses at a ratio of one to every twenty patients and to conform to the Board's nursing rules. ${ }^{80}$ In return they received half the nurse's salary and $3 s$. a week towards her board and uniform. The nursing grant was a priority on the general medical grant, which diminished the amount available for the outdoor medical service, and was discriminatory as it was paid only for poorhouse nursing, although trained district nurses were increasingly being used for the outdoor poor ${ }^{81}$ However, the Board's encouragement of trained nursing in poorhouses did raise the standard from the low levels of the mid-century. Very small poorhouses where the matron was the only female senior member of staff were advised to recruit trained nurses for this post, which would then qualify them for the grant, although pauper nurses in less responsible positions remained into the twentieth century. ${ }^{82}$ Very large poorhouses with substantial hospitals, such as Dundee East poorhouse and Barnhill, founded their own nursing schools and provided training for general, psychiatric, and fever nursing, and for midwifery. ${ }^{83}$

HOW SUCCESSFUL WAS THE BOARD OF SUPERVISION IN SHAPING THE MEDICAL SERVICES?

Generally speaking, the Board of Supervision has had few champions among historians. Geoffrey Best, for example, referring specifically to its public health functions under the Public Health (Scotland) Act of 1867, labels it "a feeble body". ${ }^{84}$ So far as the parochial medical service is concerned, can it be judged a more effective supervisory and administrative agent than such comments suggest?

However feeble the Board may appear in retrospect, it was not its feebleness but its authoritativeness that most impressed the parochial boards. By the late 1860s, a groundswell of opposition had found a parliamentary voice in the Member of Parliament for Ayrshire, William Crauford, and was sufficiently strong to cause the appointment of a Select Committee to examine poor relief in $1869 . .^{85}$ On giving

\footnotetext{
${ }^{79}$ Barony PBM special sub-committee on sick nursing, interim report, 6 and 31 October 1879; report 21 November 1879.

${ }^{80}$ Minute of the Board of Supervision, 26 March 1885.

${ }^{81}$ Stornoway PBM, 13 December 1899; Drainie PBM, 27 February 1897.

${ }^{82}$ The Haldane Papers, National Library of Scotland manuscript no. $6045 \mathrm{ff}$. 22-30 give details of nursing standards in poor law institutions in the early twentieth century.

${ }^{83}$ Barony PB House Committee Minutes, 18 November 1891. Haldane Papers, ff. 29-30. For years Barony parish was well ahead of the other parishes in the training of nurses. Adequate training facilities in the other parochial hospitals were largely a development of the early twentieth century.

${ }^{84} \mathrm{G}$. F. A. Best, 'Another part of the island: some Scottish perspectives', in H. J. Dyos and Michael Wolff (editors), The Victorian city: images and realities, London, Routledge \& Kegan Paul, 1973, vol. 1, p. 393. See also F. B. Smith, The people's health, 1830-1910, London, Croom Helm, 1979, p. 354. In this paragraph, Dr Smith appears to be confused on the differences between the Scottish and English poor laws and misinformed on the medical service.

${ }^{85}$ The aggressiveness of the Board was later referred to in Parliament by Sir C. Pearson, who stated that "there had been complaints from small local bodies who felt as if the Board were disregarding their
} 


\section{Stephanie Blackden}

evidence to the Select Committee, the minister of Bourtie, whose parochial board, it will be remembered, dispensed $7 p$ that year on medical relief, spoke for many other boards when he told the Committee that "Those who are under the new law feel themselves very helpless in carrying out their views, because it is a tyrannical power which this Board of Supervision has and exercises and we are obliged, directly and indirectly, to submit to them."

For their part, by 1869 the officials of the Board were prepared to take credit for having influenced parochial administration. When asked by a member of the Select Committee, "Do you think that the effect of the Board of Supervision has been to introduce anything like uniformity of action in the administration of law in local Boards?" the witness, a former secretary of the Board of Supervision, could answer confidently, "Undoubtedly it has; and the inspectors that go round, that is to say the officers of the Board that go round, examine all the books and see that everything is kept in uniform shape", ${ }^{87}$

Twenty years earlier, Secretary Smythe might have hesitated to express such an opinion publicly. At that time the Act was in its first years of operation, and centralized authority was still regarded with suspicion. In giving evidence to the Select Committee, officials of the Board reminded those questioning them that the Act described their role as only advisory and remonstrative, that they could only influence parishes within the limits of the Act and could not coerce them. ${ }^{88}$ Certainly, the task laid on them at the commencement of their duties in 1845 was made more difficult by inadequate powers, particularly with regard to the outdoor medical service. However, we have seen how the Board were able to use those powers they possessed, together with control over the payment of the medical relief grant and supervision through the visiting inspectorate, to impose some degree of uniformity on the parochial medical service. The Act had given the Board more direct powers over the indoor medical service through their responsibility to approve poorhouse rules and their right to dismiss unfit, incompetent, or neglectful medical officers. These powers had been used to influence poorhouse design, to introduce regulations for poorhouses (which had included minimum standards for sick-ward management) and, from the 1880 s onwards, to encourage the introduction of trained sick-nursing into all poorhouses. Further legislation outside the poor law had added to the Board's responsibilities. The Vaccination (Scotland) Act of 1863 had given them responsibility for supervising the compulsory vaccination of infants, and the Public Health (Scotland) Act of 1867 had increased the Board's powers not only over parochial boards but over all other local authorities, including town councils, police commissions, and later county councils, by making them the supervisory authority for public health procedures. Against this has to be set the loss of their responsibilities over the insane poor from 1858 , when these were given to the Board

\footnotetext{
representative character and forcing schemes upon them that they could do better without". Pearson was speaking in vindication of the Board's activities. Hansard, 22 May 1894, p. 1010.

${ }^{86}$ Select Committee, PPXI, 1870, q. 1102, p. 63.

${ }^{87}$ Select Committee, PPXI, 1869, q. 188, p. 14.

${ }^{88}$ Ibid., q. 353-358, p. 23.
} 


\section{The Board of Supervision and the Scottish Parochial Medical Service}

of Lunacy. ${ }^{89}$ However, the setback given to the Board's prestige by the critical Report of the Lunacy Commissioners in 1857 was more than offset a decade later by the powers given to them under the Public Health (Scotland) Act of 1867, and by the favourable report on their activities given by the Select Committee three years later.

Nevertheless, in assessing the success of the Board of Supervision, its limitations should also be considered. There were, after all, over eight hundred parishes varying in size from around three hundred inhabitants to over one hundred thousand, to be supervised by a small permanent staff in Edinburgh. The Act of 1845 had left the new parochial boards with a great deal of the old administrative autonomy enjoyed by the kirk sessions. Parishes that kept within the legal boundaries of the statute, managed to avoid disputes over settlement, and dispensed sufficient aliment to forestall claims for inadequate relief, were left free to run their own affairs. There were many areas where the Board had no legal powers to enforce authority and could only recommend a particular course of action. Most of these were only marginally concerned with the medical aspects of poor relief. For example, the Board had no authority over the allocation of funds by the parochial boards.

On the medical side, as we have seen, the statute left the provision of outdoor medical relief to the discretion of the individual parochial boards. No direct powers were given to the Board to frame legally enforceable rules for the guidance of parochial boards, and the only means of compelling those who neglected or refused to provide medical relief to assume their responsibilities were either application to the Court of Session for an Order or, on the receipt of a complaint by a pauper, declaring the level of medical relief in that particular case to be inadequate. The Select Committee, reporting in July 1871, recognized the need for an improved medical service. They recommended that every parochial board be required to appoint a suitably qualified medical officer, who could be removed from office only with the approval of the Board. It would be his duty to provide a dispensary furnished with the necessary medicines at or near his residence. This recommendation came to naught because the necessary legislation was not passed. Although several bills designed to improve the service were introduced into Parliament in the 1870 s and ' 80 s, none succeeded in reaching the Statute Book.9

In supervising the outdoor medical service, the Board had been able to use the rules for the medical relief grant to achieve some influence, and these certainly provided a flexible vehicle for upgrading the service from time to time, minor changes being approved as late as $1890 .^{91}$ It is therefore surprising that the Board did not make efforts to extend the same principle to poorhouse sick wards. The payment of the grant towards indoor medical relief was never connected to satisfactory application of the Board's poorhouse rules, with the exception of the nursing rules. A belated effort to do so in $\mathbf{1 8 9 0}$ was rejected on the grounds that this proposal would introduce "too substantial a change in the methods and conditions that had been stereotyped by the Local Government Act, 1889', which had recently become law. ${ }^{92}$

\footnotetext{
${ }^{89}$ Report of the Royal Commission appointed to enquire into the state oflunatic asylums in Scotland, PP 5, 1857.

${ }^{90}$ Departmental Committee, p. 10.

${ }^{91}$ Ibid., p. 12.

"I Ibid., pp. 12-13.
} 


\section{Stephanie Blackden}

Thus, the Board was powerless to prevent such abuses as the employment of pauper nurses, a problem inherited by its successors, the Local Government Board for Scotland, or even to ensure the proper separation of sick and infirm inmates from their fellows.

The care of the sick and infirm outdoor poor in the rural parishes, other than through the medical officer, was another problem. Too frequently, the sick nurses provided were elderly paupers, not far removed in their physical condition from the patients they were supposed to care for, or were neighbours paid a small sum to "drop in" from time to time. The casual sick house never became established in every parish, as the Board would have wished. The Board simply did not have the legal powers to compel compliance. In contrast, the Board did have the legal authority to oversee the compulsory vaccination of infants, and when the parochial vaccination service proved ineffective, the Board tried to tighten up procedures in $1873 .^{93}$ They reminded the parochial vaccinators that lack of vaccine lymph was no excuse, as lymph was supplied free to all vaccinators in Scotland by the Central Vaccine Institution in Edinburgh. They took the further step of stating their intention "to report to the Lord Advocate all cases in which an offence against the law should appear to have been committed", such as giving false vaccination certificates. In spite of their efforts, those infant vaccinations which were performed in Scotland were unlikely to have been carried out by the parochial vaccination service. For example, at a time when the population of the City parish in Glasgow was around 220,000 and the birth rate of the whole city was 40.29 per thousand, the parochial vaccinator reported that only 300 vaccinations had been carried out by the parochial authorities that year. ${ }^{94}$

There is perhaps the temptation to cast the parishes in the role of reactionary and inhumane bodies, more concerned with the ratepayer's pockets than the welfare of the paupers, and to view the Board of Supervision as the agency of enlightenment, battling against stingy indifference. Neither picture is totally true or false. The Board was certainly responsible, as this study has outlined, for ensuring that the destitute received a minimum standard of financial and medical relief, and the Board fulfilled that responsibility to the extent its powers permitted, being prepared to press for reforms when these were in the best interests of the service. The parochial boards were responsible for dispensing public money as well as caring for the destitute, and both Board and parishes upheld stern attitudes towards the able-bodied, the dissipated, and the undeserving, which were enshrined in Scottish parochial tradition. Some of the first poorhouses were criticized not for being stern "bastilles" but for being too comfortable for the paupers. Neither was the Board always sensible and humane, and when studying parochial records it is sometimes difficult to escape the impression that it was motivated more by a concern for administrative efficiency and the correct application of the law than by a concern for the health and welfare of the poor. The Board's promotion of poorhouses forced expensive and largely

\footnotetext{
${ }^{93}$ Board of Supervision circular, 8 January 1873 . Included in City PB Sanitary Committee Minutes, 3 February 1873.

${ }^{94}$ City PB Sanitary Committee Minutes, 4 October 1869. See also S. Blackden, 'The Poor Law and health: a study of the parochial medical service in Glasgow', in T. C. Smout (editor), The search for wealth and stability: essays presented to Michael Flinn, London, Macmillan, 1979, p. 251.
} 


\section{The Board of Supervision and the Scottish Parochial Medical Service}

underused institutions on the rural areas of Scotland. These were particularly inappropriate for the western highlands and islands. As J. P. Day has pointed out, the poor law as a whole was largely designed and administered with the lowlands in mind and ignored the special problems of remote rural areas. ${ }^{95}$ Strict conformity to rules caused a loss of flexibility in the administration of the poor law which could itself cause hardship, as in the case of the old Borders man who lay dying in a cart while officials tried to apply the correct procedures for his admission to the poorhouse. ${ }^{96}$

For their part, the parishes often showed a sympathy which the Board lacked. An over-generous interpretation of entitlement to medical relief on the part of some parishes caused the Board, in September 1885, to remind all parochial boards that medical relief could only be given to registered paupers. ${ }^{97}$ Sometimes, a local parochial board provided leadership for a medical project that the community needed. An example is Stornaway parish council, which helped set up a fund for a tuberculosis sanatorium on Lewis, even advertising in the Edinburgh and London press to get contributions from expatriates. ${ }^{98}$ In small rural parishes the inspector of the poor inevitably became the man to turn to in adversity, whether the petitioner was a pauper or not. Sometimes a parochial board, composed largely of landowners, found themselves attempting to protect their paupers from eviction by fellow landlords, striving to keep cottages in repair, or providing fuel, food, and a number of other services for the aged and infirm. ${ }^{99}$

Any assessment of the parochial medical service should look for evidence of its value in helping the sick poor. It is certainly possible to show a great increase in the extent of the service over the fifty-year period. Earlier, we looked briefly at the medical relief provided to Glasgow's sick paupers at the time of the 1884 Royal Commission on the Scottish Poor Law. If we now look forward to 1909, when another Royal Commission on the poor laws heard evidence on parochial medical care, Glasgow Parish Council still provided more medical aid than any other Scottish parish. The range of services which it now controlled was even more impressive than before. It organized a domiciliary medical service through twenty-one outdoor medical officers, one full-time. It had established dispensaries in various parts of the parish, staffed by trained apothecaries. It managed four general hospitals and two lunatic asylums. It provided pavilions for tuberculosis patients. Finally, it employed a large staff of trained doctors, nurses, lunatic attendants, ambulance drivers, and other ancillary workers. All four of Glasgow's parochial hospitals proved training facilities for nurses which qualified them for registration with the Local Government Board for Scotland and supplied the establishment with most of its nursing staff. Glasgow's parochial hospitals were certainly not as well equipped or staffed as the voluntary hospitals, and the domiciliary medical service did not give adequate care.

${ }^{95}$ Day, op. cit., note 40 above, pp. 94-95.

${ }^{96}$ Poor Law Magazine, 1889-90, 32: 402-424.

${ }^{97}$ Forty-first annual report, 1886, p. viii. Board of Supervision Circular dated 9 September 1885.

${ }^{98}$ Stornoway PCM, 26 October 1904. The gift of a sanatorium for Ross and Cromarty by Colonel and Mrs Mackenzie of Seaforth rendered a Lewis sanatorium unnecessary, and the money collected appears to have been distributed to local consumptives and their families. (Stornoway PCM, 31 March 1909.)

${ }^{99}$ See Birnie parish correspondence, letters to the inspector of the poor; Glenmuick PBM, 2 February 1848. The parochial board of Glenmuick "peremptoraly order Mr Smith [the landlord], either to remove the paupers from the houses where the cattle are kept or to remove the cattle". 


\section{Stephanie Blackden}

Even so, parish medical aid in the city did provide a fairly comprehensive health service to the sick person who could show his pauper's ticket. ${ }^{100}$

At the other end of the scale, by 1909, even the smallest parishes employed a part-time medical officer. They dispatched their sick poor needing hospital or long-term medical care into a local infirmary or the sick wards of a poorhouse. They lodged their insane poor either in a registered asylum or in a private house, under the close supervision of the Lunacy Board. Only remote islands such as Fair Isle or St Kilda fell outside this minimum medical provision.

In between these extremes, the extent of medical aid provided varied according to the size and population of the parishes. But by and large, all parishes being subject to the same laws and methods of control and supervision by the central authority, there was almost complete uniformity of practice in the administration of the poor law and its medical service. Most of the credit for this must go to the Board of Supervision and its permanent staff, whose persistent emphasis on the provision and maintenance of medical aid throughout their fifty years of office was unremitting.

However, to re-emphasize a point made earlier, the quality of care was far from uniform. In some instances it was deplorably low, as a major investigation undertaken by the Local Government Board for Scotland in 1901 was to show. ${ }^{101}$ In 1909 , there was still much to criticize in the way parochial authorities dispensed medical relief, and only when a comparison is made between the medical relief provided in 1845 and that provided in 1909 can we talk about progress.

In 1894, the Board of Supervision was replaced by the Local Government Board of Scotland and the parochial boards by the elected parish councils. The medical service which had developed by that date was thus the product of a fifty-year partnership between Board and parishes, with the major responsibility for the shape of the service lying with the Board of Supervision. Co-operation between both sides had only come gradually. In the period immediately after 1845 , the political atmosphere had been against centralization. However, the Board became more acceptable as the passage of time carried parochial administration further from the ideals and arguments surrounding the Act of 1845 , and made central supervision less of a contentious issue. During the same period, medical procedures had not stood still. As pointed out earlier in this study, a number of influences, not least of them changing attitudes towards the role of government and the causes of poverty, affected the development of the poor law and its medical service, and the Board's successes and failures should be assessed in this light. This is not to minimize the Board's influence, which was very considerable, but to remember that we are considering a period of fifty formative years in parochial and medical administration.

\section{ACKNOWLEDGEMENT}

I should like to thank Dr Barclay Johnson of Carleton University, Ottawa, for help and advice in the preparation of this article. The research for the study was made possible by a grant from the Wellcome Trust.

\footnotetext{
${ }^{100}$ Information on the parochial medical service in this period can be obtained from the Minute Books of the Glasgow Parish Council, lodged in Strathclyde Regional Archives, Glasgow.

${ }^{101}$ Report of a Departmental Committee appointed by the Local Government Board for Scotland to enquire into the system of Poor Law medical relief, PPXXXIII, 1904.
} 